\title{
Detrital-zircon geochronology of the metasedimentary rocks of north-western Graham Land
}

\author{
DAVID L. BARBEAU JR ${ }^{1 *}$, JUSTIN T. DAVIS ${ }^{1}, K^{2}$ NDRA E. MURRAY ${ }^{2}$, VICTOR VALENCIA ${ }^{2}$, \\ GEORGE E. GEHRELS ${ }^{2}$, KHANDAKER M. ZAHID ${ }^{1}$ and DAVID J. GOMBOSI ${ }^{1,3}$ \\ ${ }^{I}$ Tectonics \& Sedimentation Laboratory, Department of Earth and Ocean Sciences, University of South Carolina, \\ Columbia, SC 29208, USA \\ ${ }^{2}$ Arizona LaserChron Center, Department of Geosciences, University of Arizona, Tucson, AZ 85721, USA \\ ${ }^{3}$ present address: Department of Earth Sciences, Syracuse University, Syracuse, NY 13244, USA \\ *dbarbeau@geol.sc.edu
}

\begin{abstract}
Metasedimentary rocks constitute an important but comparatively poorly understood part of the Antarctic Peninsula. Herein we report single-grain U-Pb detrital-zircon ages from samples of the Trinity Peninsula and Botany Bay Groups of north-western Graham Land. All studied samples are dominated by a large and narrowly defined population of late Palaeozoic zircons. Significant early-middle Palaeozoic and minor Neoproterozoic and Mesoproterozoic sub-populations constitute the majority of pre-Carboniferous grains. These detrital-zircon age populations are consistent with sediment derivation entirely from western Gondwana sources. Despite the clear Gondwana signatures, our data suggest that the Trinity Peninsula Group province was either a parautochthonous peri-Gondwanan terrane later accreted to the Antarctic Peninsula, or a significant topographic barrier precluded voluminous sediment contributions from the interior of Gondwana. Statistical comparisons with similar metasedimentary complexes of southern South America, the South Shetland Islands and eastern New Zealand indicate a diversity of sediment provenance not previously recognized, but may provide a means to better determine the pre-break-up configuration of western Gondwana. Although insufficient to definitively restore Antarctic Peninsula components adjacent to South American complexes, some Trinity Peninsula Group samples exhibit robust affinities to the Miers Bluff Formation in the South Shetland Islands and the Duque de York and Main Range Metamorphic Complexes of the Patagonian Andes.
\end{abstract}

Received 18 June 2009, accepted 28 July 2009

Key words: Botany Bay Group, Gondwana, Mount Flora Formation, sediment provenance, Trinity Peninsula Group

\section{Introduction}

The Antarctic Peninsula and its proximal archipelagos (Figs $1 \&$ 2) constitute an arcuate continental landmass composed largely of granitoids and volcanic rocks. The conventional view is that these igneous rocks were emplaced in association with: 1) Carboniferous-Jurassic subduction of proto-Pacific oceanic lithosphere underneath the leading edge of western Gondwana inclusive of southern South America and West Antarctica (Pankhurst 1990, Millar et al. 2002, Vaughan \& Pankhurst 2008), 2) Middle-Late Jurassic break-up of Gondwana (Riley \& Leat 1999, Pankhurst et al. 2000), and 3) Cretaceous-Neogene subduction of Pacific-realm oceanic crust underneath the Antarctic Peninsula as West Antarctica separated from Africa and South America (Saunders et al. 1980, Leat et al. 1995, Tangeman et al. 1996). However, recent structural geology, metamorphic petrology and geochronology efforts suggest that the western portion of the Peninsula (i.e. 'Western Domain' and 'Eastern Domain' in Fig. 1) is composed of one or more allochthonous terranes that accreted to the central and eastern Peninsula in the Early Cretaceous (Kellogg \& Rowley 1989, Vaughan \& Storey 2000, Vaughan et al. 2002a, 2002b).

The exposed host rocks for many of the plutonic suites in the northern Antarctic Peninsula region largely consist of low- to intermediate-grade poorly fossiliferous turbiditic and pelagic metasedimentary rocks (Hyden \& Tanner 1981, Loske et al. 1988) that most probably accumulated in the fore-arc region of the late Palaeozoic Gondwanide/ Australide orogen and were variably incorporated into its accretionary prism (Willan 2003). In Graham Land these strata are known generally as the Trinity Peninsula Group (Fig. 1), and presumably overlie Palaeozoic basement orthogneiss and paragneiss that outcrop locally on the Peninsula (Millar et al. 2002, Flowerdew 2008). On the basis of similar sedimentology and detrital-zircon geochronology, the Trinity Peninsula Group has recently been interpreted to have formed a contiguous tectonostratigraphic body with the Duque de York metamorphic complex of the southern Chilean archipelago $\left(\sim 49-53^{\circ} \mathrm{S}\right)$ during its formation between the Late Permian and earliest Cretaceous (Hervé et al. 2006a). The LeMay and Fossil Bluff Groups of 


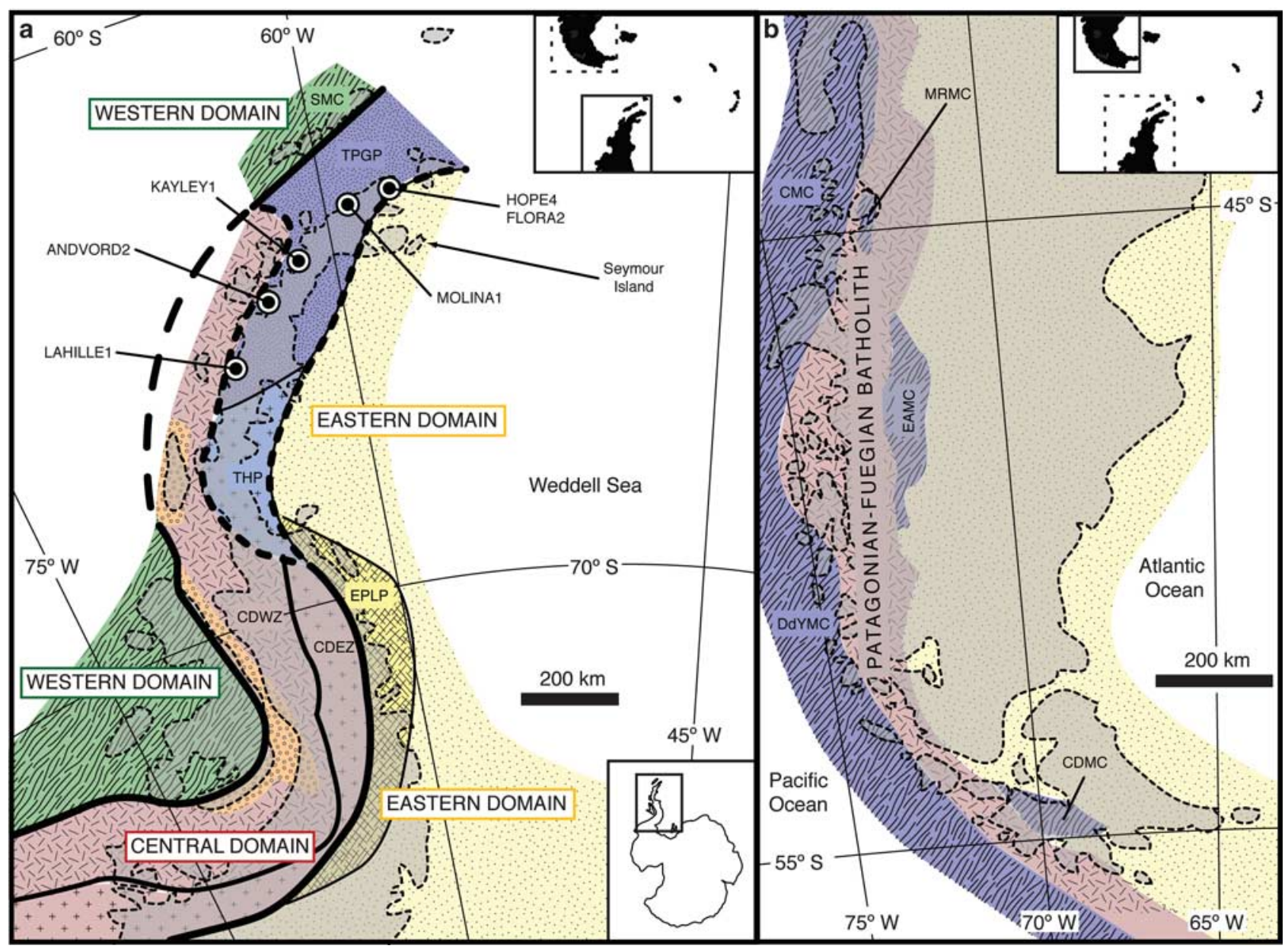

Fig. 1. a. Antarctic Peninsula depicting sample localities and tectonostratigraphic domains (modified from A.P.M. Vaughan, personal communication 2009, after Vaughan \& Storey 2000, Ferraccioli et al. 2006, Wendt et al. 2008). SMC = Scotia Metamorphic Complex, TPGP = Trinity Peninsula Group Province, THP = Target Hill Province, CDWZ = western zone of the Central Domain, $\mathrm{CDEZ}=$ eastern zone of the Central Domain, EPLP = Eastern Palmer Land Province of Eastern Domain. It is currently unclear whether the TPGP and/or THP belong to the Eastern or Central Domain. b. Southern South America depicting location of metasedimentary complexes that are lithologically similar and broadly age-equivalent to the Trinity Peninsula Group (modified from Hervé et al. 2003), MRMC = Main Range Metamorphic Complex, CMC = Chonos Metamorphic Complex, EAMC = Eastern Andean Metamorphic Complex, DdYMC $=$ Duque de York Metamorphic Complex, CDMC $=$ Cordillera Darwin Metamorphic Complex.

Alexander Island, the Miers Bluff Formation of the South Shetland Islands and the Botany Bay Group of northern Graham Land constitute other voluminous metasedimentary complexes preserved on the Antarctic Peninsula. Whereas the Botany Bay and Fossil Bluff Groups are wellconstrained as Jurassic and Jurassic-Early Cretaceous fault-bounded basin fills developed atop underlying basement, possible genetic relationships between the Trinity Peninsula Group and LeMay Group are not fully constrained. Sediment petrography and REE geochemistry suggest distinct provenances for the LeMay and Trinity Peninsula Groups (Willan 2003). Similar lithologies and depositional age constraints from low- to high-grade metasedimentary complexes in the southern Andes (Miller et al. 1987, Hervé et al. 1991) have suggested a possible genetic connection with the Trinity Peninsula Group prior to the break-up of Gondwana, although plate reconstructions are numerous, varied and poorly constrained. Further, it is not currently clear whether the Trinity Peninsula Group province falls within the allochthonous 'Western Domain' or 'Central Domain' of the accretion model (e.g. Wendt et al. 2008).

In order to test hypothetical spatial and temporal relationships among and between the metasedimentary and sedimentary rocks of the northern Antarctic Peninsula, the South Shetland Islands, the southernmost Andes, and the eastern province of New Zealand, we report the crystallization ages of detrital zircons collected from five samples of the Trinity Peninsula Group and one sample of the Mount Flora Formation of the Botany Bay Group. In total, we present $\sim 600$ new single-grain $\mathrm{U}-\mathrm{Pb}$ ages 


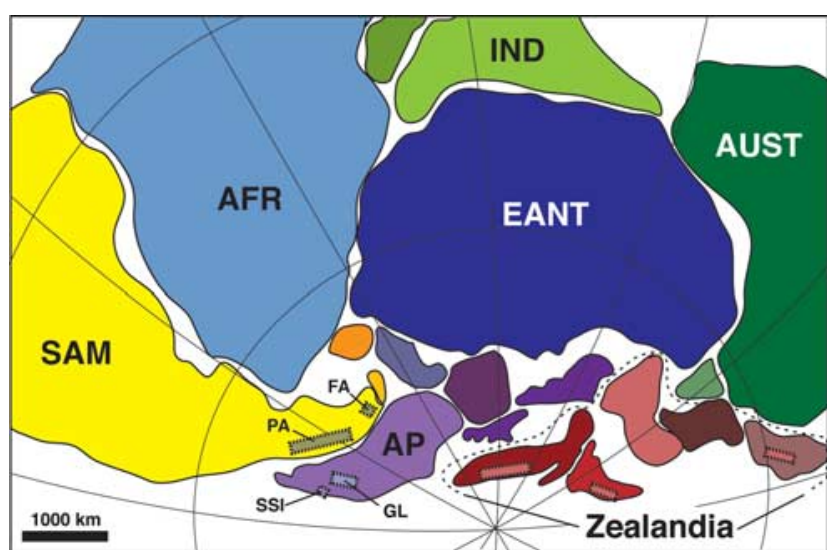

Fig. 2. Late Triassic (c. $200 \mathrm{Ma}$ ) reconstruction of Gondwana showing inferred positions of continental fragments and metasedimentary complexes. SAM = South America, $\mathrm{AFR}=$ Africa, $\mathrm{IND}=$ India, $\mathrm{EANT}=$ East Antarctica, AUST $=$ Australia, AP $=$ Antarctic Peninsula and surrounding archipelago, SSI $=$ Miers Bluff Formation of the South Shetland Islands, GL = Trinity Peninsula Group of Graham Land, $\mathrm{PA}=$ metamorphic complexes of the Patagonian Andes, $\mathrm{FA}=$ Cordillera Darwin complex of the Fuegian Andes. Modified from Lawver et al. (1998) and Adams et al. (2007).

analysed by laser-ablation inductively coupled plasma multicollector mass-spectrometry (LA-MC-ICPMS), which we compare with published $\mathrm{U}-\mathrm{Pb}$ zircon ages of selected surrounding tectonostratigraphic units. Because of its refractory nature, high concentration of radiogenic $\mathrm{U}$ (10 ppm - $1 \mathrm{wt} \%$ ), abundance within the continental crust, and durability in the supracrustal environment, zircon provides a powerful and widely employed tool for using the geochronology of detrital sediments to constrain sediment provenance. Inferences made from these provenance data can evaluate candidate tectonic and petrogenetic hypotheses.

\section{Samples}

\section{Botany Bay Group}

Sample FLORA2 comes from a dark grey, thickly bedded, ferruginous, medium-grained low-grade quartzite in the Mount Flora Formation of the Botany Bay Group collected from Mount Flora above Hope Bay in northern Graham Land $\left(63^{\circ} 24.815^{\prime} \mathrm{S}, 57^{\circ} 1.293^{\prime} \mathrm{W}\right)$.

\section{Trinity Peninsula Group}

Sample HOPE4 comes from a light brown, thickly and tabularly bedded, coarse-grained, low-grade arkosic quartzite with accessory biotite and muscovite collected from the Hope Bay Formation of the Trinity Peninsula Group on the south-eastern shore of Hope Bay below Mount Flora $\left(63^{\circ} 24.569^{\prime} \mathrm{S}, 57^{\circ} 2.345^{\prime} \mathrm{W}\right)$. Sample MOLINA1 comes from a light grey, medium- and tabularly bedded, mediumgrained, arkosic low-grade quartzite from the Legoupil
Formation of the Trinity Peninsula Group collected from the Molina Rocks south-east of Astrolabe Island in the Bransfield Strait $\left(63^{\circ} 22.356^{\prime} \mathrm{S}, \quad 58^{\circ} 26.868^{\prime} \mathrm{W}\right)$. Sample KAYLEY1 comes from medium grey, medium-bedded, medium-grained, low-grade lithic quartzite from the Legoupil Formation of the Trinity Peninsula Group collected from Sprightly Island near the mouth of the Cayley Glacier east of Brabant and Cobalescou islands in northern Graham Land $\left(64^{\circ} 17.002^{\prime} \mathrm{S}, 61^{\circ} 4.067^{\prime} \mathrm{W}\right)$. Sample ANDVORD2 comes from a dark grey, thinly and tabularly bedded, coarse-grained, low-grade quartzite from the Legoupil Formation of the Trinity Peninsula Group collected from the south-eastern shore of Andvord Bay near Forbes Point and the mouth of Rudolph Glacier $\left(64^{\circ} 53.114^{\prime} \mathrm{S}, 62^{\circ} 28.560^{\prime} \mathrm{W}\right)$. Sample LAHILLE1 comes from a dark grey, medium- and tabularly bedded, coarsegrained, low-grade lithic quartzite from the Legoupil Formation of the Trinity Peninsula Group collected from a cove on the southern shore of Lahille Island in Leroux Bay $\left(65^{\circ} 33.278^{\prime} \mathrm{S}, 64^{\circ} 23.973^{\prime} \mathrm{W}\right)$.

\section{Methods}

Sample preparation was performed at the Tectonics \& Sedimentation Laboratory at the University of South Carolina. U-Pb zircon geochronology was performed at the Arizona LaserChron Center in the Department of Geosciences at the University of Arizona.

\section{Sample collection and preparation}

For each sample, approximately $10-15 \mathrm{~kg}$ of quartzite was collected from coastal outcrops with minimal evidence of intrusions, hydrothermal precipitation or other possible contaminants. Collected samples were disaggregated with a Bico WD Chipmunk jaw crusher and a Bico UD pulverizer until all grains would pass through a 500 micron disposable mesh. High-density minerals were concentrated with a MD Mineral Technologies MK-2 Gemeni table and handoperated ABS plastic gold pans. Secondary heavy mineral concentration was completed with the heavy liquid LST (a lithium heteropolytungstate solution with specific gravity of 2.90) in $10 \mathrm{ml}$ centrifuge tubes. The centrifuge tubes were frozen in liquid $\mathrm{N}_{2}$ after which the heavy fractions were excised from the LST ice. After removal of strongly magnetic grains, the resulting heavy fractions were processed step-wise via 0.25 ampere increments (from 0.25-1.75 A) using a S.G. Frantz L1 isodynamic magnetic separator operating at horizontal and vertical angles of $15^{\circ}$ and $25^{\circ}$, respectively. To eliminate possible biases associated with hand-picking, the resulting zircon-rich separates were poured into Buehler ring forms along with chips of a zircon standard (SL) and bonded in place using double-sided tape and epoxy resin. The resulting mounts were gently polished using wet sandpaper of 2500 and 3000 grit in order to expose the grain cores. 
Table I. P-values from Kolmogorov-Smirnov test of detrital-zircon age spectra similarity*: Antarctica and South America.

\begin{tabular}{|c|c|c|c|c|c|c|c|c|c|}
\hline \multirow{2}{*}{$\begin{array}{l}\text { Metamorphic } \\
\text { complex }\end{array}$} & \multirow[t]{2}{*}{ Sample } & \multirow[t]{2}{*}{ Population } & \multicolumn{6}{|c|}{ Trinity Peninsula Group } & \multirow{2}{*}{$\begin{array}{l}\text { BBG }^{\#} \\
\text { FLORA2 }\end{array}$} \\
\hline & & & HOPE4 & MOLINA1 & KAYLEY1 & ANDVORD2 & LAHILLE1 & Composite $^{\dagger}$ & \\
\hline \multirow[t]{8}{*}{ Trinity Peninsula Group } & HOPE4 & All & & 0.000 & 0.000 & 0.000 & 0.000 & 0.000 & 0.000 \\
\hline & & $<350 \mathrm{Ma}$ & & 0.719 & 0.000 & 0.099 & 0.006 & 0.060 & 0.000 \\
\hline & MOLINA1 & All & 0.000 & & 0.077 & 0.999 & 0.147 & 0.581 & 0.001 \\
\hline & & $<350 \mathrm{Ma}$ & 0.719 & & 0.000 & 0.642 & 0.000 & 0.831 & 0.039 \\
\hline & KAYLEY1 & All & 0.000 & 0.077 & & 0.202 & 0.000 & 0.002 & 0.000 \\
\hline & & $<350 \mathrm{Ma}$ & 0.000 & 0.000 & & 0.004 & 0.000 & 0.000 & 0.000 \\
\hline & LAHILLE1 & All & 0.000 & 0.147 & 0.000 & 0.277 & & 0.164 & 0.000 \\
\hline & & $<350 \mathrm{Ma}$ & 0.006 & 0.000 & 0.000 & 0.000 & & 0.000 & 0.000 \\
\hline \multirow[t]{2}{*}{ Botany Bay Group } & FLORA2 & All & 0.000 & 0.001 & 0.000 & 0.007 & 0.000 & 0.004 & \\
\hline & & $<350 \mathrm{Ma}$ & 0.000 & 0.039 & 0.000 & 0.383 & 0.000 & 0.006 & \\
\hline \multirow[t]{2}{*}{ Miers Bluff Formation+ } & VF14 & All & 0.024 & 0.002 & 0.000 & 0.005 & 0.066 & 0.002 & 0.000 \\
\hline & & $<350 \mathrm{Ma}$ & 0.000 & 0.000 & 0.000 & 0.000 & 0.032 & 0.000 & 0.000 \\
\hline \multirow[t]{8}{*}{ Duque de York Complex } & AL1 & All & 0.436 & 0.011 & 0.000 & 0.040 & 0.002 & 0.056 & 0.385 \\
\hline & & $<350 \mathrm{Ma}$ & 0.813 & 0.999 & 0.000 & 0.930 & 0.003 & 0.999 & 0.057 \\
\hline & MD3 & All & 0.949 & 0.000 & 0.000 & 0.001 & 0.000 & 0.001 & 0.133 \\
\hline & & $<350 \mathrm{Ma}$ & 0.680 & 0.955 & 0.000 & 0.956 & 0.006 & 0.998 & 0.044 \\
\hline & MD32 & All & 0.083 & 0.002 & 0.012 & 0.009 & 0.000 & 0.009 & 0.859 \\
\hline & & $<350 \mathrm{Ma}$ & 0.164 & 0.647 & 0.003 & 0.999 & 0.000 & 0.931 & 0.240 \\
\hline & Composite $^{\dagger}$ & All & 0.000 & 0.000 & 0.000 & 0.000 & 0.000 & 0.000 & 0.000 \\
\hline & & $<350 \mathrm{Ma}$ & 0.245 & 0.925 & 0.000 & 0.969 & 0.000 & 0.998 & 0.009 \\
\hline \multirow[t]{4}{*}{ Chonos Complex } & CE96-03 & All & 0.000 & 0.255 & 0.025 & 0.337 & 0.704 & 0.185 & 0.006 \\
\hline & & $<350 \mathrm{Ma}$ & 0.011 & 0.009 & 0.000 & 0.018 & 0.120 & 0.006 & 0.000 \\
\hline & CE-96-25 & All & 0.000 & 0.111 & 0.653 & 0.307 & 0.034 & 0.497 & 0.017 \\
\hline & & $<350 \mathrm{Ma}$ & 0.027 & 0.159 & 0.180 & 0.489 & 0.001 & 0.198 & 0.221 \\
\hline \multirow{2}{*}{ Main Range Complex* } & CE96-29 + MA21 & All & 0.000 & 0.969 & 0.410 & 0.982 & 0.201 & 0.370 & 0.009 \\
\hline & & $<350 \mathrm{Ma}$ & 0.000 & 0.007 & 0.005 & 0.008 & 0.000 & 0.000 & 0.001 \\
\hline \multirow[t]{16}{*}{ Eastern Andes Complex } & FF99-01 & All & 0.000 & 0.001 & 0.000 & 0.001 & 0.007 & 0.000 & 0.000 \\
\hline & & $<350 \mathrm{Ma}$ & $\mathrm{n} / \mathrm{a}$ & $\mathrm{n} / \mathrm{a}$ & $\mathrm{n} / \mathrm{a}$ & $\mathrm{n} / \mathrm{a}$ & $\mathrm{n} / \mathrm{a}$ & $\mathrm{n} / \mathrm{a}$ & $\mathrm{n} / \mathrm{a}$ \\
\hline & FF99-05 & All & 0.000 & 0.137 & 0.154 & 0.181 & 0.053 & 0.015 & 0.000 \\
\hline & & $<350 \mathrm{Ma}$ & 0.013 & 0.110 & 0.405 & 0.473 & 0.002 & 0.342 & 0.126 \\
\hline & FO98-P17 & All & 0.000 & 0.071 & 0.016 & 0.047 & 0.058 & 0.001 & 0.000 \\
\hline & & $<350 \mathrm{Ma}$ & 0.004 & 0.068 & 0.233 & 0.168 & 0.004 & 0.096 & 0.046 \\
\hline & PS98-01 & All & 0.000 & 0.000 & 0.000 & 0.000 & 0.000 & 0.000 & 0.000 \\
\hline & & $<350 \mathrm{Ma}$ & $\mathrm{n} / \mathrm{a}$ & $\mathrm{n} / \mathrm{a}$ & $\mathrm{n} / \mathrm{a}$ & $\mathrm{n} / \mathrm{a}$ & $\mathrm{n} / \mathrm{a}$ & $\mathrm{n} / \mathrm{a}$ & $\mathrm{n} / \mathrm{a}$ \\
\hline & SE98-08 & All & 0.000 & 0.002 & 0.000 & 0.001 & 0.009 & 0.000 & 0.000 \\
\hline & & $<350 \mathrm{Ma}$ & $\mathrm{n} / \mathrm{a}$ & $\mathrm{n} / \mathrm{a}$ & $\mathrm{n} / \mathrm{a}$ & $\mathrm{n} / \mathrm{a}$ & $\mathrm{n} / \mathrm{a}$ & $\mathrm{n} / \mathrm{a}$ & $\mathrm{n} / \mathrm{a}$ \\
\hline & SI99-28C & All & 0.000 & 0.000 & 0.000 & 0.000 & 0.001 & 0.000 & 0.000 \\
\hline & & $<350 \mathrm{Ma}$ & $\mathrm{n} / \mathrm{a}$ & $\mathrm{n} / \mathrm{a}$ & $\mathrm{n} / \mathrm{a}$ & $\mathrm{n} / \mathrm{a}$ & $\mathrm{n} / \mathrm{a}$ & $\mathrm{n} / \mathrm{a}$ & $\mathrm{n} / \mathrm{a}$ \\
\hline & VS11A & All & 0.000 & 0.000 & 0.000 & 0.000 & 0.000 & 0.000 & 0.000 \\
\hline & & $<350 \mathrm{Ma}$ & $\mathrm{n} / \mathrm{a}$ & $\mathrm{n} / \mathrm{a}$ & $\mathrm{n} / \mathrm{a}$ & $\mathrm{n} / \mathrm{a}$ & $\mathrm{n} / \mathrm{a}$ & $\mathrm{n} / \mathrm{a}$ & $\mathrm{n} / \mathrm{a}$ \\
\hline & Composite $^{\dagger}$ & All & 0.000 & 0.000 & 0.000 & 0.000 & 0.000 & 0.000 & 0.000 \\
\hline & & $<350 \mathrm{Ma}$ & 0.004 & 0.158 & 0.003 & 0.525 & 0.000 & 0.228 & 0.039 \\
\hline \multirow[t]{2}{*}{ Darwin Complex ${ }^{\S}$} & Sonia1 & All & 0.000 & 0.002 & 0.000 & 0.001 & 0.000 & 0.000 & 0.000 \\
\hline & & $<350 \mathrm{Ma}$ & 0.000 & 0.000 & 0.999 & 0.030 & 0.000 & 0.003 & 0.003 \\
\hline
\end{tabular}

Values in bold indicate passage of the K-S test.

* K-S test at $95 \%$ confidence level compares cumulative distribution functions constructed from ages and uncertainties. ${ }^{\dagger}$ Composite age spectra from all related samples. ${ }^{\#}$ Botany Bay Group. + SHRIMP data from Hervé et al. (2006a). ${ }^{\star}$ SHRIMP data from Hervé et al. (2003). ${ }^{\S}$ LA-MC-ICPMS data from Barbeau et al. (2009). 
Table II. P-values from Kolmogorov-Smirnov test of detrital-zircon age spectra similarity*: Antarctica and New Zealand

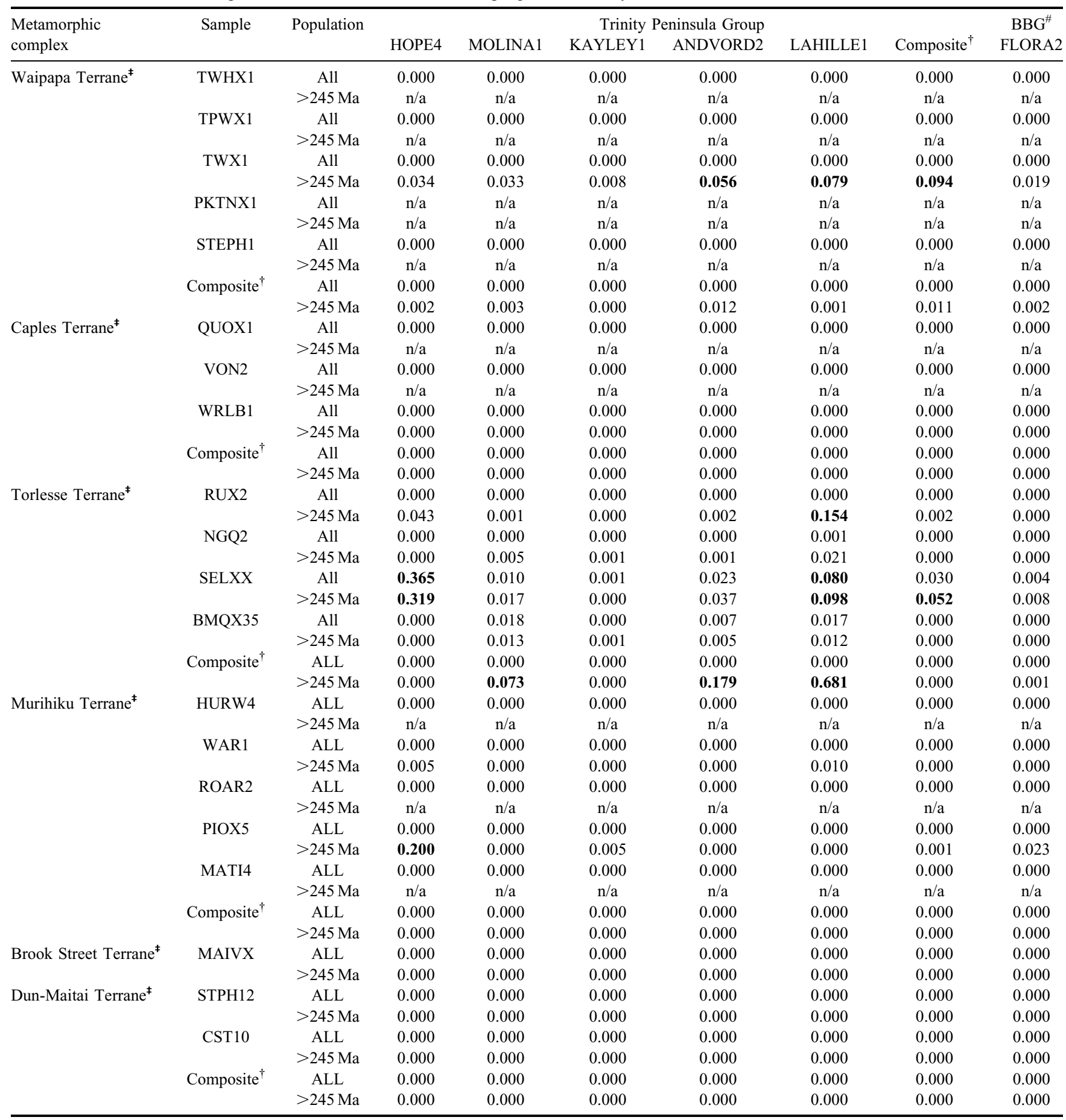

Values in bold indicate passage of the K-S test.

$*$ K-S test at $95 \%$ confidence level compares cumulative distribution functions constructed from ages and uncertainties. ${ }^{\dagger}$ Composite age spectra from all related samples. ${ }^{\#}$ Botany Bay Group. ${ }^{\ddagger}$ LA-MC-ICPMS data from Adams et al. (2007).

\section{U-Pb geochronology}

$\mathrm{U}-\mathrm{Pb}$ detrital-zircon geochronology was conducted by laser-ablation multi-collector inductively coupled plasma mass-spectrometry (LA-MC-ICPMS) in two sample runs conducted on consecutive days during late May 2009. Analysis utilized grain-ablation with a DUV193 ArF exciplex laser with a spot diameter of $25 \mu \mathrm{m}$ aimed at the centre of individual grains. The ablated material was carried in He gas into the plasma source of a GVI Isoprobe, which is 


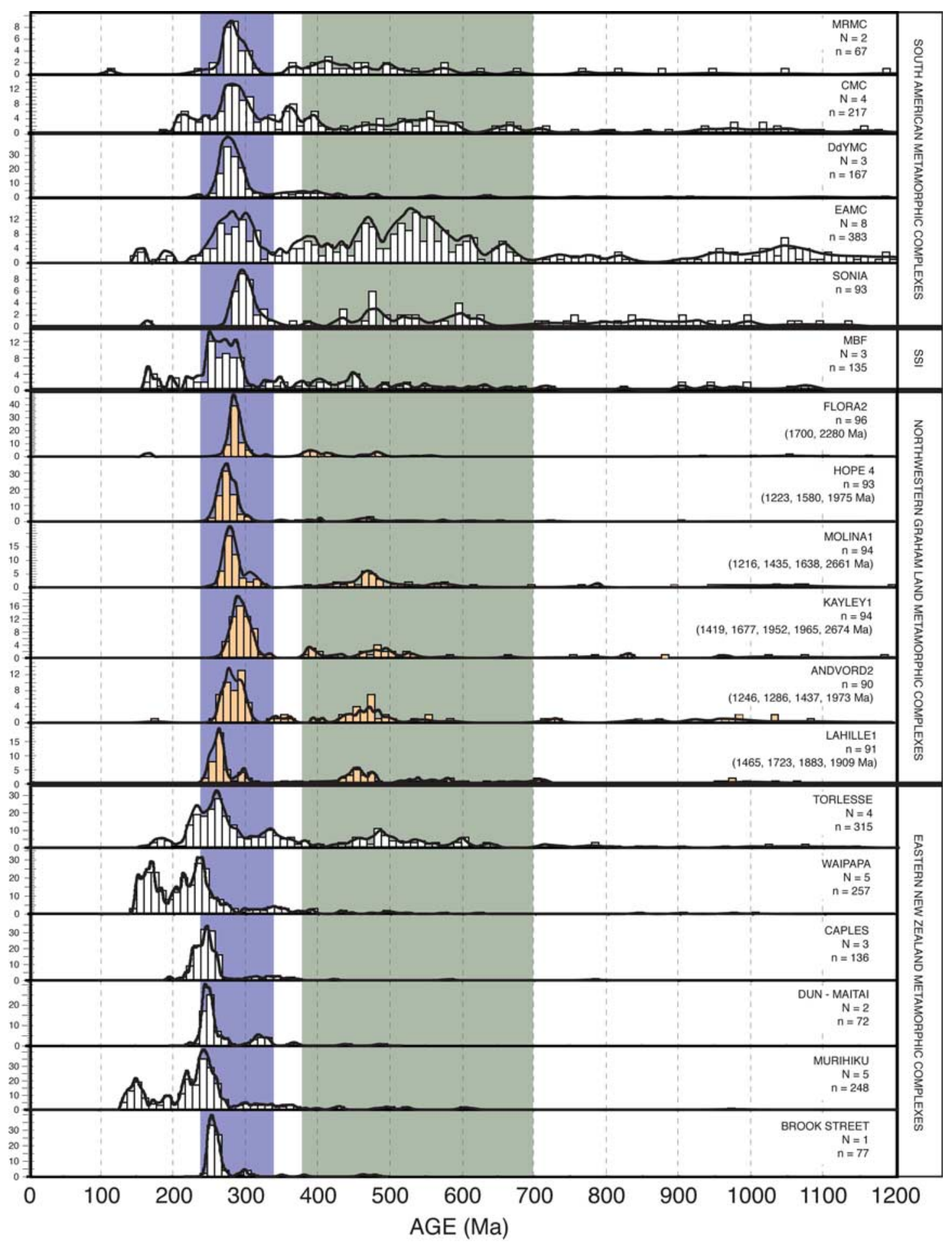

Fig. 3. Probability plots and histograms depicting U-Pb age distributions of detrital-zircon populations from metasedimentary samples of southern South America (Hervé et al. 2003, Barbeau et al. 2009), Livingston Island of the South Shetland Islands (SSI, Hervé et al. 2006b), eastern New Zealand (Adams et al. 2007) and north-western Graham Land (orange histograms, this study). MRMC $=$ Main Range Metamorphic Complex, CMC $=$ Chonos Metamorphic Complex, DdYMC $=$ Duque de York Metamorphic Complex, EAMC = Eastern Andean Metamorphic Complex, SONIA1 = Sample from the Cordillera Darwin Metamorphic Complex, $\mathrm{MBF}=$ Miers Bluff Formation. Samples from eastern New Zealand metamorphic complexes are grouped and named by their tectonostratigraphic terranes (Adams et al. 2007). Violet polygon indicates age range of prominent late Palaeozoic zircon population common to Trinity Peninsula Group samples. Green polygon indicates Neoproterozoic-early Palaeozoic zircon populations common to several samples. 
equipped with a flight tube of sufficient width such that $\mathrm{U}$, $\mathrm{Th}$, and $\mathrm{Pb}$ isotopes are measured simultaneously. All measurements were made in static mode, using $10^{11} \Omega$ Faraday detectors for ${ }^{238} \mathrm{U},{ }^{232} \mathrm{Th},{ }^{208} \mathrm{~Pb}$, and ${ }^{206} \mathrm{~Pb}$, a $10^{12} \Omega$ Faraday collector for ${ }^{207} \mathrm{~Pb}$, and an ion-counting channel for ${ }^{204} \mathrm{~Pb}$. Ion yields were $\sim 1.0 \mathrm{mV}$ per ppm. Each analysis consisted of one $12 \mathrm{sec}$ integration with the laser off, twelve $1 \mathrm{sec}$ integrations with the laser firing, and a $30 \mathrm{sec}$ delay to purge for the next analysis. Each resulting ablation pit is $\sim 15 \mu \mathrm{m}$ in depth. For each analysis, measurement errors typically resulted in $\sim 1-2 \%(2 \sigma)$ age uncertainty. Common $\mathrm{Pb}$ correction was accomplished by using the measured ${ }^{204} \mathrm{~Pb}$ and assuming an initial $\mathrm{Pb}$ composition from Stacey \& Kramers (1975) with uncertainties of 1.0 for ${ }^{206} \mathrm{~Pb} /{ }^{204} \mathrm{~Pb}$ and 0.3 for ${ }^{207} \mathrm{~Pb} /{ }^{204} \mathrm{~Pb}$. Our measurement of ${ }^{204} \mathrm{~Pb}$ is unaffected by the presence of ${ }^{204} \mathrm{Hg}$ because backgrounds are measured on peaks (thereby subtracting any background ${ }^{204} \mathrm{Hg}$ and ${ }^{204} \mathrm{~Pb}$ ), and because very little $\mathrm{Hg}$ is present in the plasmatorch's argon gas. Inter-element apparent fractionation of $\mathrm{Pb} / \mathrm{U}$ is generally $20 \%$, whereas apparent fractionation of $\mathrm{Pb}$ isotopes is generally less than $2 \%$. In-run analysis of fragments of a large zircon standard (SL: $564 \pm 4 \mathrm{Ma}, 2 \sigma$ ) after every fifth unknown was used to correct for these fractionations. Interpreted ages are based on ${ }^{206} \mathrm{~Pb}^{*} / 238 \mathrm{U}$ for $<1.0 \mathrm{Ga}$ grains and on ${ }^{206} \mathrm{~Pb}^{*} /{ }^{207} \mathrm{~Pb} *$ for $>1.0 \mathrm{Ga}$ grains. Analyses are evaluated during and after data acquisition to ensure that retained analyses do not contain significant changes in age, which would indicate intersection of age boundaries. Analyses that yielded large variations $(\sim 10 \%)$ in $\mathrm{U}$ and $\mathrm{Pb}$ isotope ratios acquired during grain-ablation are presumed to result from a mixing of core and rim ages and are hence excluded from interpretations. In order to avoid biasing against older grains, which are more susceptible to lead-loss due to increasing radiation damage with age, we employ discordance filters that include all grains that are $<30 \%$ discordant or $<5 \%$ reverse discordant (by comparison of ${ }^{206} \mathrm{~Pb}^{*} /{ }^{238} \mathrm{U}$ and ${ }^{206} \mathrm{~Pb}^{*} /{ }^{207} \mathrm{~Pb}^{*}$ ages). Analyses that were $>30 \%$ discordant or $>5 \%$ reverse discordant were tagged for further investigation. Because of the exponential improvement in ${ }^{206} \mathrm{~Pb}^{*} /{ }^{207} \mathrm{~Pb} *$ age precision with increasing age, the concordance of tagged grains $>600 \mathrm{Ma}$ were then assessed by comparison of ${ }^{206} \mathrm{~Pb} * / 238 \mathrm{U}$ and ${ }^{207} \mathrm{~Pb}^{*} / 235 \mathrm{U}$ ages. All such grains failing the aforementioned discordance filters were then excluded from interpretations (indicated in red on Table S1 available at www.journals.cambridge.org/jid_ANS).

\section{Statistical analyses}

We performed statistical comparisons between the age distributions of our individual samples and composite sample suites with those previously reported from related units using the Kolmogorov-Smirnov (K-S) test. The K-S test calculates the maximum probability distance between the cumulative distribution functions (CDFs) of two sets of age distributions. If the observed probability distance is greater

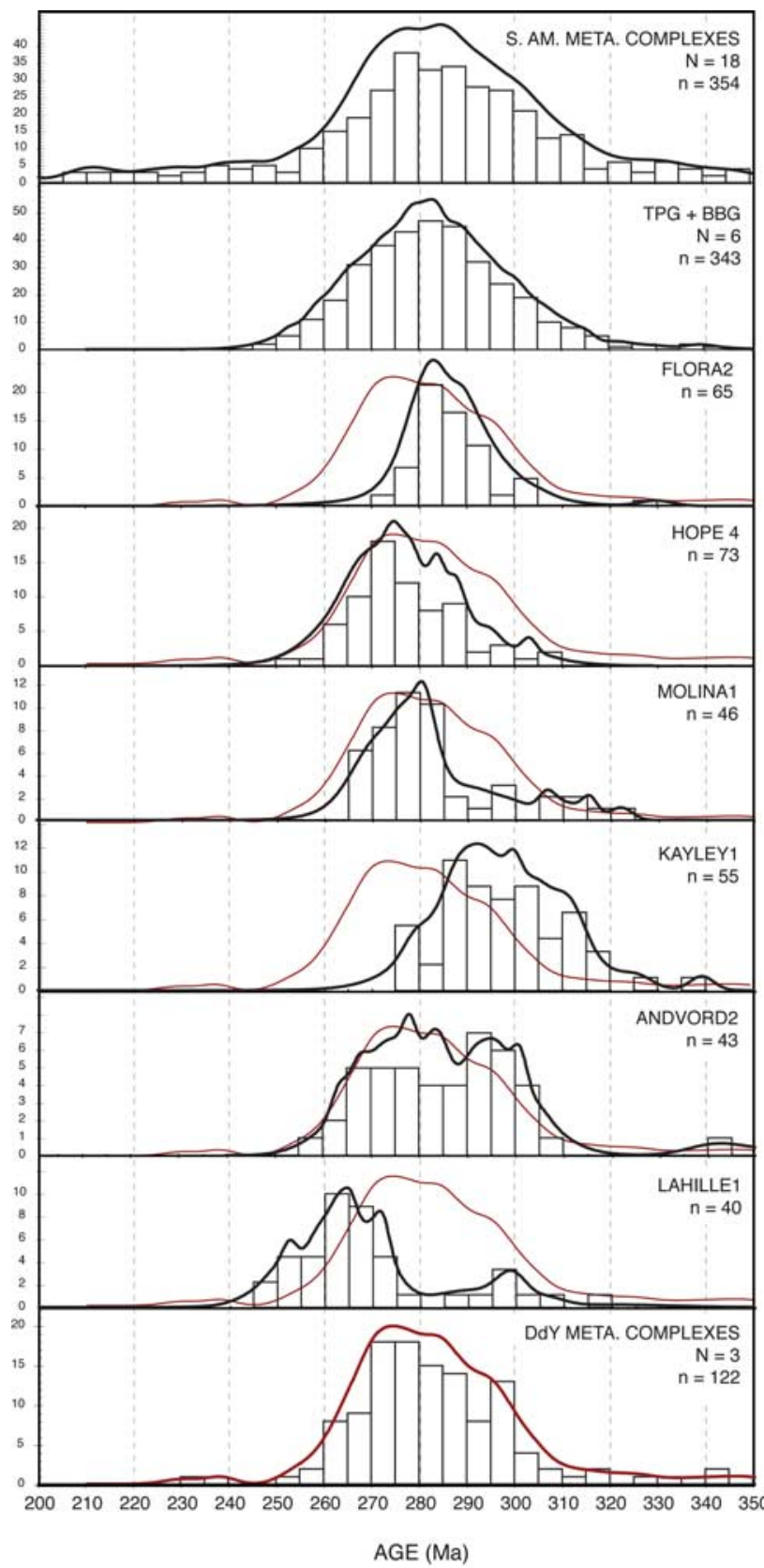

Fig. 4. Probability plots of U-Pb detrital-zircon ages $<350 \mathrm{Ma}$ in north-western Graham Land metamorphic complexes (this study) and South American metamorphic complexes exposed in the southern Andes (Hervé et al. 2003, Barbeau et al. 2009). TPG = Trinity Peninsula Group, BBG = Botany Bay Group, DdY = Duque de York. Red line indicates overlay of Duque de York metamorphic complex detrital-zircon age probability plots (re-plotted from Hervé et al. 2003).

than a critical distance defined by the chosen confidence level and the number of ages ( $n$ ) contributing to the CDFs, the K-S test fails and the two age distributions are unlikely to have come from the same parent population. We used K-S tests to test similarities and differences between 1) single samples, 
and 2) composite sample suites of genetically related strata. We also compared single samples (if sufficiently large) to composite sample suites. In each of these comparisons, we conducted K-S tests on three different sets or subsets of data: First, we conducted K-S tests using all usable grains in a given sample or sample suite. Because of the dominance of Carboniferous-Triassic aged grains in Trinity Peninsula Group, Botany Bay Group, Miers Bluff Formation and South American samples, we also performed K-S tests on those samples' $<350$ Ma sub-populations. Whereas many samples from the eastern province of New Zealand have abundant Middle Triassic or younger grains (Adams et al. 2007) largely absent from our Trinity Peninsula and Botany Bay Group samples, we also compared our samples with the $>245 \mathrm{Ma}$ sub-populations of New Zealand metasedimentary complex samples.

In our K-S analyses, we employed CDFs constructed from the ages and uncertainties of the analysed data, excluding those ages that fail the aforementioned filters (Table S1). We chose a 95\% confidence interval, such that resulting p-values $>0.050$ pass the K-S test, whereas those $<0.050$ fail. Although we conducted K-S tests for all combinations of age sets and subsets indicated in Tables I \& II, subsets with $n<25$ are not reported (n/a).

\section{Results}

In Table S1 of the online data repository, we present common lead-corrected single-grain isotopic ratios, ages and associated data for Trinity Peninsula Group and Botany Bay Group detrital zircons analysed in this study. Unless otherwise stated, uncertainties reported in this table and the rest of the manuscript are at the $1 \sigma$ level, and include only measurement errors. In Figs $3 \& 4$ we present $\mathrm{U}-\mathrm{Pb}$ age probability plots of these data for comparison to the age distributions of selected candidate equivalent- and sourceunits from the South Shetland Islands, southern South America and the eastern province of New Zealand. All analysed samples presented herein contain similar distributions of age populations with minor variations. Late Palaeozoic populations are predominant in each sample $(59 \pm 13 \%(1 \sigma)$ of each sample's zircons, range $47-80 \%$ ), although the probability peak of each sample's late Palaeozoic population vary between 260 and 290 Ma. Two Trinity Peninsula Group samples have distinct late Palaeozoic sub-peaks at c. 305-315 Ma. Each sample contains early-middle Palaeozoic populations although the size $(21 \pm 7 \%$, range $11-28 \%)$, number, and age range of these populations vary considerably by sample. The early-middle Palaeozoic populations are larger and broader in the outboard (western) Trinity Peninsula Group samples $(25 \pm 4 \%)$ than in HOPE4 $(11 \%)$ or the Botany Bay Group sample FLORA2 (12\%), which were both collected in the Hope Bay region in the central part of the northernmost Antarctic Peninsula. The ANDVORD2 and FLORA2 samples have single- and two-grain Middle Jurassic populations, respectively. Other populations are small and are not common to all samples but include miscellaneous Neoproterozoic and Mesoproterozoic populations. Of all of the grains analysed, only thirteen grains (2\%) are Palaeoproterozoic or older $(>1.6 \mathrm{Ga})$.

\section{Trinity Peninsula Group}

Sample LAHILLE1 $(n=91)$ contains a predominant population of 246-276 Ma grains (39\%, peak at c. $260 \mathrm{Ma})$ that is nearly contiguous with a lesser population of 286-320 Ma grains (8\%, peak at c. $305 \mathrm{Ma})$. LAHILLE1 also contains a significant population of 424-480 Ma grains (20\%, peaks at c. 455 and $475 \mathrm{Ma}$ ), as well as broad, lesser $516-717 \mathrm{Ma}(17 \%$, peaks at $540 \mathrm{Ma}, 580 \mathrm{Ma}$ and $710 \mathrm{Ma})$, 955-1066 Ma (7\%, peak at $1000 \mathrm{Ma})$ and 351-403 Ma (4\%) populations.

The late Palaeozoic population from sample ANDVORD2 $(n=90)$ spans $259-307 \mathrm{Ma}(50 \%$ of analysed ANDVORD2 grains) with a well-defined probability peak centred on $c$. $280 \mathrm{Ma}$. ANDVORD2 contains a significant subsidiary early Palaeozoic population composed of $21 \%$ of analysed grains and spanning 435-503 Ma with a peak centred on c. $470 \mathrm{Ma}$. In addition to these prominent age distributions, minor ANDVORD2 sub-populations include those with ages of 950-1300 Ma (12\%), 340-360 Ma (5\%), 550-600 Ma (4\%), $700-750 \mathrm{Ma}(3 \%), 397-410 \mathrm{Ma}(2 \%)$ as well as individual Mesoproterozoic (1437 Ma) and Palaeoproterozoic (1973 Ma) grains. ANDVORD2 contains a single $176.0 \pm 13.9 \mathrm{Ma}$ grain, but with moderately high $[\mathrm{U}] /[\mathrm{Th}](3.9)$, [U] $(675 \mathrm{ppm})$ and ${ }^{206} \mathrm{~Pb} *{ }^{238} \mathrm{U}:{ }^{207} \mathrm{~Pb}^{*}{ }^{235} \mathrm{U}$ age discordance $(27 \%)$.

Sample KAYLEY1 $(n=94)$ contains a predominant population of ages spanning $276-339 \mathrm{Ma}(59 \%)$ and a peak centred on c. 295 Ma. KAYLEY1 also contains significant subordinate age populations of $c$. $462-535 \mathrm{Ma}(15 \%$, peak at c. $500 \mathrm{Ma})$ and c. $390-435(8 \%$, peak at c. $395 \mathrm{Ma})$. The remaining KAYLEY1 grains constitute several isolated Neoproterozoic, Mesoproterozoic and Palaeoproterozoic single grains as well as one Late Archaean grain (2674 Ma).

MOLINA1 $(n=94)$ contains a dominant $266-323 \mathrm{Ma}$ population $(51 \%$, prominent peak at $270 \mathrm{Ma}$, sub-peak at $315 \mathrm{Ma})$ and a significant $382-537 \mathrm{Ma}$ population $(28 \%$; peak at $470 \mathrm{Ma}$ ). Lesser populations include those with late Mesoproterozoic (8\%, peak at $1040 \mathrm{Ma})$ and latest Neoproterozoic ages $(4 \%$, peak at $570 \mathrm{Ma})$ as well as one Late Archaean grain $(2661 \mathrm{Ma})$ and several isolated Proterozoic grains.

The predominant age population in sample HOPE4 $(n=93)$ ranges between $255-310 \mathrm{Ma}(80 \%$ of analysed HOPE4 grains) with a well-defined probability peak centred on c. $280 \mathrm{Ma}$. HOPE4 also contains small miscellaneous early-middle Palaeozoic (11\%), Neoproterozoic (4\%) and older Mesoproterozoic and Palaeoproterozoic (5\%) peaks. 


\section{Botany Bay Group}

Sample FLORA2 $(\mathrm{n}=96)$ contains a predominant population of 270-304 Ma grains (67\% of analysed FLORA2 grains), with its peak centred on $280 \mathrm{Ma}$. Subsidiary populations include those with ages of $380-420 \mathrm{Ma}(12 \%), 940-1162 \mathrm{Ma}(7 \%)$, and $462-490 \mathrm{Ma}(6 \%)$ as well as individual Mesoproterozoic $(1700 \mathrm{Ma})$ and Palaeoproterozoic grains (2280 Ma). The youngest two zircons constitute a Middle-Late Jurassic peak of 162-168 Ma. One of the Jurassic grains has moderately high $[\mathrm{U}] /[\mathrm{Th}](3.6),[\mathrm{U}](501 \mathrm{ppm})$ and is slightly reverse discordant $\left(-1.8 \%\right.$ in ${ }^{206} \mathrm{~Pb}^{*}{ }^{238} \mathrm{U}:{ }^{207} \mathrm{~Pb}^{*} /{ }^{235} \mathrm{U}$ ages), whereas the other has high $[\mathrm{U}](756 \mathrm{ppm})$, but low $[\mathrm{U}] /[\mathrm{Th}]$ (1.6) and discordance $\left(4.5 \%\right.$ in $\left.{ }^{206} \mathrm{~Pb}^{*}{ }^{238} \mathrm{U}:{ }^{206} \mathrm{~Pb}^{*} /{ }^{207} \mathrm{~Pb}^{*}\right)$.

\section{Kolmogorov-Smirnov comparisons}

\section{Trinity Peninsula Group}

Our new samples from the Trinity Peninsula Group contain generally similar age distributions, with minor, but significant variations between samples (Figs $3 \& 4$ ). In the upper part of Table I, we present the p-values from K-S comparisons between our Trinity Peninsula Group samples. In the remainder of Table I and all of Table II, we also present the results of K-S testing of samples from similar metasedimentary complexes of the southern Andes (Hervé \& Fanning 2001, Hervé et al. 2003, Barbeau et al. 2009), the South Shetland Islands (Hervé et al. 2006b), and the eastern province of New Zealand (Adams et al. 2007), all of which have been considered to be genetically related to the Trinity Peninsula Group.

In intra-group comparisons between the Trinity Peninsula Group samples, ANDVORD2 and MOLINA1 pass K-S tests for both complete populations and $<350 \mathrm{Ma}$ sub-populations. The complete population of KAYLEY1 and MOLINA1 pass K-S. The $<350 \mathrm{Ma}$ sub-populations of HOPE4, ANDVORD2 and MOLINA1 all pass K-S comparisons, but HOPE4 fails K-S with the complete populations of MOLINA1 and ANDVORD2. The complete populations of ANDVORD2 and KAYLEY1 pass K-S, although their $<350 \mathrm{Ma}$ sub-populations do not. LAHILLE1 fails both K-S tests with all other individual Trinity Peninsula Group samples, except comparison with the complete zircon populations of MOLINA1 and ANDVORD2. HOPE4 and KAYLEY1 fail K-S comparisons with both complete populations and $<350$ Ma sub-populations.

In comparisons with metasedimentary samples of the Miers Bluff Formation (Hervé et al. 2006b) from Livingston Island of the South Shetland Island group (Figs $1 \& 2$ ), Trinity Peninsula Group samples pass $25 \%$ of 36 K-S tests. LAHILLE1 passes $83 \%$ of six tests; whereas ANDVORD2 and MOLINA1 pass one-third and one-sixth of tests, respectively.

In comparisons with similar metamorphic complexes known in the southern Andes (Figs 1 \& 2: Hervé \&
Fanning 2001, Hervé et al. 2003, Barbeau et al. 2009), Trinity Peninsula Group samples pass $30 \%$ of 240 K-S tests. HOPE4 passes all eight K-S tests with Duque de York Metamorphic Complex (DdYDMC) samples, but less than one-quarter of K-S tests with all other complexes. ANDVORD2 passes 75\% of K-S tests with the Main Range Metamorphic Complex (MRMC) samples, $60 \%$ of ten tests with Chonos Metamorphic Complex (CMC) samples, 50\% of eight tests with DdYMC samples, and $25 \%$ of sixteen tests with Eastern Andean Metamorphic Complex (EAMC) samples. MOLINA1 passes $75 \%$ of four tests with MRMC samples, $50 \%$ of tests with DdYMC (eight tests) and CMC (ten tests) samples, and 31\% of sixteen tests with EAMC samples. LAHILLE1 passes 50\% of ten K-S tests with CMC samples, $25 \%$ of four tests with MRMC samples, $13 \%$ of sixteen tests with EAMC samples, but fails all tests with DdYMC and Cordillera Darwin Metamorphic Complex (CDMC) samples. KAYLEY1 passes $50 \%$ of four K-S tests with MRMC samples, $20 \%$ of ten tests with CMC samples, $19 \%$ of sixteen tests with EAMC samples and fails all tests with DdYMC and CDMC samples.

In comparisons with similar metamorphic complexes (Adams et al. 2007) known in the eastern province of New Zealand (Fig. 2), Trinity Peninsula Group samples pass only $4 \%$ of $300 \mathrm{~K}-\mathrm{S}$ tests that compare both complete zircon populations, and the sub-populations of $>245 \mathrm{Ma}$ grains (Table II). LAHILLE1 passes $40 \%$ of ten K-S tests with the Torlesse terrane and $8 \%$ of twelve tests with the Waipapa terrane. HOPE4 passes $20 \%$ of ten K-S tests with metasedimentary samples from the Torlesse terrane and one of twelve tests with the Murihiku terrane. MOLINA1 and ANDVORD2 each pass one of ten tests with samples from the Torlesse terrane; ANDVORD2 also passes one of twelve tests with samples from the Waipapa terrane. KAYLEY1 fails all fifty tests.

\section{Botany Bay Group}

The Botany Bay Group/Mount Flora Formation sample FLORA2 fails all K-S tests with the complete zircon populations of Trinity Peninsula Group samples of this study. FLORA2 also fails K-S tests with all but ANDVORD2's $<350$ Ma sub-population. FLORA2 passes $63 \%$ of eight tests with DdYMC samples, $50 \%$ of four K-S tests with MRMC samples, $20 \%$ of ten tests with CMC samples, and $6 \%$ of 16 tests with EAMC samples. It fails all tests with CDMC samples. FLORA2 fails all K-S tests with Miers Bluff Formation samples from the South Shetland Islands (Table I) as well as all tests with samples from the eastern province of New Zealand (Table II).

\section{Discussion}

Provenance of Trinity Peninsula Group detrital zircons

We interpret the predominant late Palaeozoic (c. 240-320 Ma) detrital-zircon populations in all analysed samples (Figs 3 
\& 4) as having ultimately been derived from magmatic rocks associated with the Gondwanide/Australide orogen formed by terrane accretion (Pankhurst et al. 2006) and protracted subduction of proto-Pacific oceanic crust underneath the continental margin of western Gondwana (Adams et al. 2007, Vaughan \& Pankhurst 2008). As indicated by the variety of peaks and sub-peaks in each sample (Fig. 4), these detrital-zircon populations were most probably derived from a number of Permo-Carboniferous felsic and intermediate magmatic rocks, potentially including a) early Carboniferous granitoids currently known in Marie Byrd Land, Target Hill of eastern Graham Land, and the North Patagonian Massif (Pankhurst et al. 1998, 2006, Millar et al. 2002), b) Middle-Late Carboniferous granitoids and intermediate plutons known in the North Patagonian Massif and Thurston Island (Leat et al. 1993, Pankhurst et al. 2006), and c) Permian granitoids and migmatites known in eastern Graham Land, western and eastern Palmer Land, Marie Byrd Land, and the North Patagonian Massif (Pankhurst et al. 1992, 1998, Rapela \& Pankhurst 1996, Bradshaw et al. 1997, Millar et al. 2002).

Zircon-bearing rocks with ages that fall within the range of the Siluro-Devonian (375-425 Ma) age population recognized in several Trinity Peninsula Group samples occur in the Target Hill orthogneiss of eastern Graham Land (Millar et al. 2002), the Mount Eissenger orthogneiss of north-western Palmer Land (Millar et al. 2002), Marie Byrd Land (Pankhurst et al. 1998), as well as in the extra-Andean regions of both northern and southern Patagonia (Pankhurst et al. 2006). Rocks with ages that occur within the range of the Middle Cambrian to Early Silurian (430-530 Ma) populations recognized in each Trinity Peninsula Group sample (as well as FLORA2) occur in several locations throughout West Antarctica, including the Campbell Ridges, Mount Eissenger, the Welch Mountains and Mount Nordhill in Palmer Land (Millar et al. 2002, Flowerdew et al. 2006), parts of Marie Byrd Land (Pankhurst et al. 1998), and granitoid cobbles known from Horseshoe Island (Tangeman et al. 1996) and in the View Point Formation of eastern Graham Land (Millar et al. 2002). Similarly aged felsic and intermediate rocks are also known in the Colorado Basin and northern Patagonia (Pankhurst et al. 2006). The miscellaneous, minor Proterozoic zircon populations in Trinity Peninsula Group samples have broadly coeval ages known in West Antarctica, East Antarctica, southern Africa, and South America north of Patagonia (Jacobs et al. 1998, Lucassen et al. 2000, Millar et al. 2001).

Together, these observations suggest that the Trinity Peninsula Group sediments were derived from regional sources endemic to western Gondwana prior to its breakup. With the present analysis alone, it is difficult to robustly discern between the aforementioned candidate source terranes in any detail. Future integration of additional samples and other provenance indicators, including perhaps double-dated grains, may provide the necessary insight to distinguish source regions.

\section{Mount Flora Formation of the Botany Bay Group}

To a first-order, the detrital-zircon composition of Botany Bay Group sample FLORA2 resembles the age distributions of the Trinity Peninsula Group samples described herein (Fig. 3) as well as samples presented graphically or descriptively by other workers (Loske et al. 1988, Hervé et al. 2006a, Castillo et al. in press). These results suggest three possible interpretations of the Botany Bay Group: 1) The Botany Bay Group is equivalent to (parts of) the Trinity Peninsula Group, in which case the Trinity Peninsula Group is younger than conventionally considered, 2) Botany Bay Group detrital sediments were derived from the Trinity Peninsula Group, or 3) Botany Bay Group detrital sediments have a common provenance with the Trinity Peninsula Group. At present it is not possible to conclusively determine which of the three hypotheses is most likely, but integration of our new data with other geological observations provides some insight and guidance for future work.

In regards to hypothesis (1), the depositional age of the Mount Flora Formation from which FLORA2 was collected is well constrained as $c .167 \mathrm{Ma}$ (Hunter et al. 2005). In contrast, biostratigraphic and lithostratigraphic considerations suggest that the Trinity Peninsula Group is most probably Triassic in age (Thomson 1975, Dalziel et al. 1981, Smellie \& Millar 1995). Maximum depositional ages of the Trinity Peninsula Group indicated by our detrital-zircon data suggest it is no older than c. 250-280 Ma, which along with the aforementioned biostratigraphic interpretations suggest it wholly predates deposition of Botany Bay Group strata. However, a single $176 \pm 13.9 \mathrm{Ma}$ grain in sample ANDVORD2 raises the possibility that parts of the Trinity Peninsula Group could be no older than Middle Jurassic, and is comparable with the $164.9 \pm 3.3 \mathrm{Ma}$ two-grain peak in FLORA2. Further, cross-cutting relationships, calcareous fossils and detrital-zircon geochronology indicate that parts of the Miers Bluff Formation - which has been considered equivalent to the Trinity Peninsula Group (Shu et al. 2000) are as young as the Jurassic or Cretaceous (Stoykova et al. 2002, Pimpirev et al. 2006, Hervé et al. 2006b). However, the comparatively large age uncertainty, high [U], and discordance of the young ANDVORD2 zircon strongly suggests lead-loss from an older grain, perhaps by Jurassic metamorphism as reflected in the grain's somewhat elevated $[\mathrm{U}] /[\mathrm{Th}]$. Thus, no aspect of our new data robustly supports a correlation between the studied parts of the Trinity Peninsula Group and the Mount Flora Formation of the Botany Bay Group.

Despite FLORA2's failure of $90 \%$ of ten K-S test comparisons with the Trinity Peninsula Group zircon populations, it is plausible that hypothesis (2) is correct and FLORA2 was derived directly from the Trinity Peninsula Group. The wide variability of the age ranges and peaks of late Palaeozoic populations (Fig. 4) and the varying presence or absence of pre-Carboniferous age 
populations in the Trinity Peninsula Group samples (Fig. 3) indicate a considerable diversity of generally similar but statistically distinct sediment sources feeding the Trinity Peninsula Group. This diversity amongst the Trinity Peninsula Group samples would seemingly favour failure of K-S comparisons of FLORA2 and the small number of Trinity Peninsula Group age distributions presented herein even if FLORA2 were derived directly from Trinity Peninsula Group strata. Nonetheless, considering the stratigraphic, structural and geographic proximity of samples HOPE4 and FLORA2, it is surprising that these samples have such different zircon compositions (Figs 3 $\& 4$ ), suggesting that the parsimonious hypothesis (2) may be incorrect.

In light of the caveats described above, it is conceivable that hypothesis (3) is correct and the Botany Bay Group detritus was derived from similar sediment sources as those that fed the Trinity Peninsula Group senso lato. This interpretation would align with the preponderance of evidence indicating distinct ages for the two Groups, as well as the demonstrated variability in sediment compositions reaching Graham Land. If indeed the Trinity Peninsula Group significantly precedes deposition of the Botany Bay Group, it is somewhat surprising their detrital zircon compositions are so similar - were the Trinity Peninsula Group to have accumulated entirely during the subduction of proto-Pacific oceanic lithosphere underneath a contiguous Gondwana, it seems unlikely for the Botany Bay Group to have accumulated sediment from similar sources in similar abundances in a tectonic setting (Gondwana break-up) that was fundamentally different from the region's late Palaeozoic configuration.

\section{Correlation with other metamorphic complexes}

Comparison of the detrital-zircon geochronology of Trinity Peninsula Group samples with those of candidate equivalents or relatives in South America, the South Shetland Islands, and New Zealand: 1) suggests one or more common sources for parts of the Trinity Peninsula Group and the Miers Bluff Formation, and 2) strongly favours genetic relationships with South American counterparts over those of Zealandia despite significant commonalities between all groups.

Whereas one detrital-zircon sample of the Miers Bluff Formation from the South Shetland Islands demonstrates conclusive evidence of a depositional age bracketed between the Middle Jurassic and Early Cretaceous (Hervé et al. 2006b) that would preclude equivalency with our Trinity Peninsula Group samples, a second sample suggests parts of the Miers Bluff Formation may have been deposited in the Middle Triassic (Hervé et al. 2006b), in agreement with previous $\mathrm{Rb}-\mathrm{Sr}$ age constraints (Willan et al. 1994). Considering geographic proximity and the demonstrated age-distribution similarities between our samples LAHILLE1 (especially), ANDVORD2 and
MOLINA1 with reported Miers Bluff Formation samples (Table I), it is probable that older zircons of the Miers Bluff Formation were derived from a common source as the Trinity Peninsula Group. Further, it is plausible that parts of the Trinity Peninsula Group are equivalent to the lower Miers Bluff Formation.

In comparison, metamorphic complexes of the eastern province of New Zealand are significantly less comparable to our samples from the Trinity Peninsula Group. The sampled units have overlap with several components of the eastern New Zealand samples (Fig. 3), supporting a common petrogenesis along the leading subduction margin of Gondwana (Fig. 2). However, the significant components of Triassic and younger grains in most New Zealand samples preclude the possibility of equivalency with the studied intervals of the Trinity Peninsula Group.

In contrast, the strong age-distribution similarities between the Trinity Peninsula Group and similar metamorphic complexes exposed in the southern Andes may offer insight into the pre-break-up configuration of the West Antarctica and South American components of Gondwana. At first glance, the Trinity Peninsula Group and South American metamorphic complexes display considerable similarities, yet a closer examination reveals a significant diversity that may permit piercing point restorations. The comparatively small preCarboniferous detrital-zircon populations of the studied Trinity Peninsula Group samples do not provide sufficient data to definitively test candidate connections between different metamorphic complexes. However, marked and substantial variations in the abundant late Palaeozoic $(<350 \mathrm{Ma})$ zircon populations of the Trinity Peninsula Group samples reported herein (Fig. 4) offer potential applicability to assessing candidate connections with South American metamorphic complex samples (Hervé et al. 2003, Barbeau et al. 2009).

Although samples HOPE4, ANDVORD2 and MOLINA1 contain statistically significant similarities with most samples from the Duque de York metamorphic complex (Hervé et al. 2003), KAYLEY1 and LAHILLE1 are sufficiently different from the DdYMC to suggest that the metamorphic complexes are too heterogeneous to definitively interpret as wholly contiguous and equivalent units as has been recently suggested (Hervé et al. 2006a). This internal complexity is further supported by K-S test results that indicate LAHILLE1's distinctive nature in comparison to all other analysed Trinity Peninsula Group samples, and the dissimilarities between KAYLEY1, HOPE4 and MOLINA1.

The late Palaeozoic zircon populations of KAYLEY1, MOLINA1 and ANDVORD2 have statistical similarities with the Main Range Metamorphic Complex of the interior of the central Patagonian Andes (Fig. 1). In light of the current geographic proximity of these three Trinity Peninsula Group samples (Fig. 1), these results may support the 'tight-fit' palaeogeographic model that restores the Antarctic Peninsula outboard (west in present 
coordinates) of Patagonia prior to Gondwana break-up (Dalziel \& Elliot 1982, Lawver et al. 1998, Hervé et al. 2006a). However, the even more robust statistical connection between DdYMC samples and HOPE4, the latter of which resides at the northern margin of the Antarctic Peninsula, would require $180^{\circ}$ of vertical-axis rotation in order to simultaneously juxtapose the MRMC with the central western Trinity Peninsula Group province. Perhaps further detrital-zircon and other types of provenance analysis of the MRMC, DdYMC and Trinity Peninsula Group will offer a more geologically pleasing reconstruction that does not require such extreme and currently unsubstantiated rotations.

\section{Terrane accretion in the Antarctic Peninsula}

Despite the existence of sediment sources in adjacent parts of West Gondwana that could account for all detrital-zircon populations currently known in the Trinity Peninsula Group, the relative paucity of pre-Carboniferous zircons and the universal dominance of a comparatively narrow Permo-Carboniferous age population (Fig. 3) in our samples suggest sediment derivation from relatively small drainage basins as would be expected from allochthonous or parautochthonous terranes. In comparison, pre-Carboniferous zircons are abundant and widely recognized in the retro-arc rocks of the EAMC in Patagonia (Fig. 3), suggesting that these sediments have a Gondwanan provenance (Hervé et al. 2003) and accumulated in an autochthonous setting in proximity and with unimpeded access to cratonic interiors. Considering the absence of large populations of preCarboniferous zircons in the studied Trinity Peninsula Group samples, the detrital-zircon geochronology of the Trinity Peninsula Group indicates accumulation in sedimentary isolation from Gondwana proper. On this basis, the Trinity Peninsula Group might be considered part of the accreted Western or Central Domains of Vaughan \& Storey (2000). However, in light of the Gondwanan signatures of its zircons, if the Trinity Peninsula Group constitutes part of an accreted terrane it is probably not fartravelled ('exotic') but rather a parautochthonous body that was temporarily detached from Gondwana before being re-accreted in the Mesozoic or Cenozoic. Thus, using the EAMC (Fig. 3) as a indicator of the zircon composition of autochthonous Gondwanan late Palaeozoic-early Mesozoic(?) metamorphic complexes, the detrital-zircon composition of the Trinity Peninsula Group presented herein does not overwhelmingly support an Eastern Domain autochthonous interpretation for the Trinity Peninsula Group province (Fig. 1). Alternatively, the existence of a topographic barrier and drainage divide between the Trinity Peninsula Group and the Gondwanan interior could account for the relative absence of preCarboniferous zircons, in which case the Trinity Peninsula Group province could be part of the Eastern Domain.

\section{Acknowledgements}

This research was primarily supported by International Polar Year grant ANT-0732995 to DLB from the National Science Foundation Office of Polar Programs. Additional funding came from NSF grant EAR-0732436 to GG. The United States Antarctic Program, Edison Choest Offshore and Raytheon Polar Services Company provided logistical support under the direction of J. Evans, S. Flanagan and H. Baker; W. Guenthner, B. Kliesen, D. Ellsberg, C. Denker, M. King and T. Koffman provided field assistance; A. Brown, S. Herron and C. Boutwell provided sample preparation assistance; M. Baker provided instrument support at the Arizona LaserChron Center; J. Guynn provided K-S analytical software and A.P.M. Vaughan provided valuable insight into the regional geology of the Antarctic Peninsula. Constructive reviews by M. Flowerdew, P. Leat and A.P.M. Vaughan significantly improved the quality of the manuscript.

DLB devised and acquired funding for the project. DLB, KEM and DJG conducted field sampling. JD supervised sample preparation. VV and GG supervised sample analysis by KEM and JD. DLB interpreted the results and wrote the manuscript with editorial and interpretive contributions from all co-authors. DJG assisted with K-S statistics and interpretations.

\section{References}

Adams, C.J., Campbell, H.J. \& Griffin, W.L. 2007. Provenance comparisons of Permian to Jurassic tectonostratigraphic terranes in New Zealand: perspectives from detrital zircon age patterns. Geological Magazine, 144, 701-729.

Barbeau, D.L., Olivero, E.B., Swanson-Hysell, N.L., Zahid, K.M., Murray, K.E. \& Gehrels, G.E. 2009. Detrital-zircon geochronology of the eastern Magallanes foreland basin: implications for Eocene kinematics of the northern Scotia Arc and Drake Passage. Earth and Planetary Science Letters, 284, 489-503.

Bradshaw, J.D., Pankhurst, R.J., Weaver, S.D., Storey, B.C., Muir, R.J. \& IRELAND, T.R. 1997. New Zealand superterranes recognized in Marie Byrd Land and Thurston Island. In RicCI, C.A., ed. The Antarctic region: geological evolution and processes. Siena: Terra Antarctica Publications, 429-436.

Castillo, P., Lacassie, J.P., Hervé, F. \& Fanning, C.M. In press. Sedimentary provenance of Trinity Peninsula Group, Antarctic Peninsula: petrography, geochemistry and SHRIMP U-Pb zircon age constraints. Geophysical Research Abstracts, 11.

Dalziel, I.W.D. \& Elliot, D.H. 1982. West Antarctica: problem child of Gondwanaland. Tectonics, 1, 3-19.

Dalziel, I.W.D., Elliot, D.H., Jones, D.L., Thomson, J.W., Thomson, M.R.A., Wells, N.A. \& Zinsmeister, W.J. 1981. The geological significance of some Triassic microfossils from the South Orkney Islands, Scotia Ridge. Geological Magazine, 118, 15-25.

Ferraccioli, F., Jones, P.C., Vaughan, A.P.M. \& Leat, P.T. 2006. New aerogeophysical view of the Antarctic Peninsula: more pieces, less puzzle. Geophysical Research Letters, 33, 10.1029/2005GL024636.

Flowerdew, M. 2008. On the age and relation between metamorphic gneisses and the Trinity Peninsula Group, Bowman Coast, Graham Land, Antarctica. Antarctic Science, 20, 511-512.

Flowerdew, M.J., Millar, I.L., Vaughan, A.P.M., Horstwood, M.S.A. \& FANNING, C.M. 2006. The source of granitic gneisses and migmatites in the Antarctic Peninsula; a combined U-Pb SHRIMP and laser ablation Hf isotope study of complex zircons. Contributions to Mineralogy and Petrology, 151, 751-768. 
Hervé, F. \& Fanning, C.M. 2001. Late Triassic detrital zircons in metaturbidites of the Chonos Metamorphic Complex, southern Chile. Revista Geológica de Chile, 28, 91-104.

Hervé, F., Fanning, C.M. \& Pankhurst, R.J. 2003. Detrital zircon age patterns and provenance in the metamorphic complexes of Southern Chile. Journal of South American Earth Sciences, 16, $107-123$.

Hervé, F., Miller, H. \& Pimpirev, C.H. 2006a. Patagonia-Antarctica connections before Gondwana break-up. In FutTerer, D.K., Damaske, D., Kleinschmidt, G., Miller, H. \& Tessensohn, F., eds. Antarctica: contributions to global earth sciences. Berlin: Springer, 217-228.

Hervé, F., Faúndez, V., Brix, M. \& Fanning, C.M. 2006b. Jurassic sedimentation of the Miers Bluff Formation, Livingston Island, Antarctica: evidence from SHRIMP U-Pb ages of detrital and plutonic zircons. Antarctic Science, 18, 229-238.

Hervé, F., Loske, W., Miller, H. \& Pankhurst, R.J. 1991. Chronology of provenance, deposition and metamorphism of deformed fore-arc sequences, southern Scotia Arc. In Thomson, M.R.A., Crame, J.A. \& Thomson, J.W., eds. Geological evolution of Antarctica. Cambridge: Cambridge University Press, 429-435.

Hunter, M.A., Cantrill, D.J., Flowerdew, M.J. \& Millar, I.L. 2005. Mid-Jurassic age for the Botany Bay Group; implications for Weddell Sea basin creation and Southern Hemisphere biostratigraphy. Journal of the Geological Society, 162, 745-748.

Hyden, G. \& Tanner, P.W.G. 1981. Late Palaeozoic-early Mesozoic forearc basin sedimentary rocks at the Pacific margin in western Antarctica. Geologische Rundschau, 70, 529-541.

Jacobs, J., Fanning, C.M., Henjes-Kunst, F., Olesch, M. \& Paech, H.J. 1998. Contribution of the Mozambique Belt into East Antarctica: Grenville-age metamorphism and polyphase Pan-African high-grade events in Central Dronning Maud Land. Journal of Geology, 106, 385-406.

KellogG, K.S. \& Rowley, P.D. 1989. Structural geology and tectonics of the Orville Coast region, southern Antarctica Peninsula. US Geological Survey Professional Paper, 1498, 1-25.

Lawver, L.A., Dalziel, I.W.D. \& Gahagan, L.M. 1998. A tight fit early Mesozoic Gondwana, a plate reconstruction perspective. Memoirs of the National Institute of Polar Research Special Issue, 53, 214-229.

Leat, P.T., Storey, B.C. \& Pankhurst, R.J. 1993. Geochemistry of Palaeozoic-Mesozoic Pacific Rim orogenic magmatism, Thurston Island area, West Antarctica. Antarctic Science, 5, 281-296.

Leat, P.T., Scarrow, J.H. \& Millar, I.L. 1995. On the Antarctic Peninsula batholith. Geological Magazine, 132, 399-412.

Loske, W.P., Miller, H. \& Kramm, U. 1988. U-Pb systematics of detrital zircons from low-grade metamorphic sandstones of the Trinity Peninsula Group (Antarctica). Journal of South American Earth Sciences, 1, 301-307.

Lucassen, F., Becchio, R., Wilke, H.G., Franz, G., Thirlwall, M.F., Viramonte, J. \& Wemmer, K.P. 2000. Proterozoic-Paleozoic development of the basement of the Central Andes (18-26 $\mathrm{S})$ - a mobile belt of the South American craton. Journal of South American Earth Sciences, 13, 697-715.

Millar, I.L., Pankhurst, R.J. \& Fanning, C.M. 2002. Basement chronology of the Antarctic Peninsula: recurrent magmatism and anatexis in the Palaeozoic Gondwana margin. Journal of the Geological Society, 159, 145-157.

Millar, I.L., Willan, R.C.R., Wareham, C.D. \& Boyce, A.J. 2001. The role of crustal and mantle sources in the genesis of granitoids of the Antarctic Peninsula and adjacent crustal blocks. Journal of the Geological Society, 158, 855-867.

Miller, H., Loske, W.P. \& Kramm, U. 1987. Zircon provenance and Gondwana reconstruction: $\mathrm{U}-\mathrm{Pb}$ data of detrital zircons from Triassic Trinity Peninsula Formation metasandstones. Polarforschung, 57, $59-69$.
Pankhurst, R.J. 1990. The Paleozoic and Andean magmatic arcs of West Antarctica and southern South America. Geological Society of America Special Paper, 241, 1-17

Pankhurst, R.J., Rapela, C.W., Fanning, C.M. \& Márquez, M. 2006. Gondwanide continental collision and the origin of Patagonia. Earth Science Reviews, 76, 235-257.

Pankhurst, R.J., Riley, T.R., Fanning, C.M. \& Kelley, S. 2000. Episodic silicic volcanism in Patagonia and the Antarctic Peninsula: chronology of magmatism associated with the break-up of Gondwana. Journal of Petrology, 41, 605-625.

Pankhurst, R.J., Rapela, C.W., Caminos, R., Llambias, E. \& Parica, C. 1992. A revised age for the granites of the central Somuncura Batholith, North Patagonian Massif. Journal of South American Earth Sciences, 5 , 321-325.

Pankhurst, R.J., Weaver, S.D., Bradshaw, J.D., Storey, B.C. \& Ireland, T.R. 1998. Geochronology and geochemistry of pre-Jurassic superterranes in Marie Byrd Land, Antarctica. Journal of Geophysical Research, B103, 2529-2547.

Pimpirev, C., Stoykova, K., Ivanov, M. \& Dimov, V. 2006. The Miers Bluff Formation, Livingston Island, South Shetland Islands - part of the Late Jurassic-Cretaceous depositional history of the Antarctic Peninsula. In Futterer, D.K., Damaske, D., Kleinschmidt, G., Miller, H. \& Tessensohn, F., eds. Antarctica: contributions to global earth sciences. Berlin: Springer, 249-254.

Rapela, C.W. \& Pankhurst, R.J. 1996. Monzonite suites; the innermost Cordilleran plutonism of Patagonia. Geological Society of America Special Paper, 315, 193-203.

RiLey, T.R. \& LEAT, P.T. 1999. Large volume silicic volcanism along the proto-Pacific margin of Gondwana: lithological and stratigraphical investigations from the Antarctic Peninsula. Geological Magazine, 136, $1-16$.

Saunders, A.D., Tarney, J. \& Weaver, S.D. 1980. Transverse geochemical variations across the Antarctic Peninsula; implications for the genesis of calc-alkaline magmas. Earth and Planetary Science Letters, 46, 344-360.

Shu, O., XI-Guang, D., Yan-Bin, S., Xiang-Shen, Z. \& Xiao-Han, L. 2000. Late Triassic plant microfossils from Miers Bluff Formation of Livingston Island, South Shetland Islands, Antarctica. Antarctic Science, 12, 217-228.

Smellie, J. \& Millar, I.L. 1995. New K-Ar isotopic ages of schists from Nordenskjöld Coast, Antarctic Peninsula; oldest part of the Trinity Peninsula Group? Antarctic Science, 7, 191-196.

Stacey, J.S. \& Kramers, J.D. 1975. Approximation of terrestrial lead isotope evolution by a two-stage model. Earth and Planetary Science Letters, 26, 207-221.

Stoykova, K., Pimpirev, C.H. \& Dimov, D. 2002. Calcareous nannofossils from the Miers Bluff Formation (Livingston Island, South Shetland Islands, Antarctica): first evidence for a late Cretaceous age. Nannoplankton Research, 24, 166-167.

Tangeman, J.A., Mukasa, S.B. \& Grunow, A.M. 1996. Zircon U-Pb geochronology of plutonic rocks from the Antarctic Peninsula: confirmation of the presence of unexposed Paleozoic crust. Tectonics, 15, 1309-1324.

Thomson, M.R.A. 1975. New palaeontological and lithological observations on the Legoupil Formation, north-west Antarctic Peninsula. British Antarctic Survey Bulletin, Nos 41-42, 169-185.

VAughan, A.P.M. \& PANKhURST, R.J. 2008. Tectonic overview of the West Gondwana margin. Gondwana Research, 13, 150-162.

Vaughan, A.P.M. \& Storey, B.C. 2000. The eastern Palmer Land shear zone: a new terrane accretion model for the Mesozoic development of the Antarctic Peninsula. Journal of the Geological Society, 157, 1243-1256.

Vaughan, A.P.M., Kelley, S.P. \& Storey, B.C. 2002a. Mid-Cretaceous ductile deformation on the Eastern Palmer Land Shear Zone, Antarctica, and implications for timing of Mesozoic terrane collision. Geological Magazine, 139, 465-471. 
Vaughan, A.P.M., Pankhurst, R.J. \& Fanning, C.M. 2002b. A midCretaceous age for the Palmer Land event, Antarctic Peninsula: implications for terrane accretion timing and Gondwana palaeolatitudes. Journal of the Geological Society, 159, 113-116.

Wendt, A.S., Vaughan, A.P.M. \& TAte, A. 2008. Metamorphic rocks in the Antarctic Peninsula region. Geological Magazine, 145, 655-676.
Willan, R.C.R. 2003. Provenance of Triassic-Cretaceous sandstones in the Antarctic Peninsula: implications for terrane models during Gondwana break-up. Journal of Sedimentary Research, 73, 1062-1077. Willan, R.C.R., Pankhurst, R.J. \& Hervé, F. 1994. A probable early Triassic age for the Miers Bluff Formation, Livingston Island, South Shetland Islands. Antarctic Science, 6, 401-408. 